\title{
Hydrography and water masses in the southeastern Arabian Sea during March-June 2003
}

\author{
S S C Shenoi ${ }^{1 *}$, D Shankar ${ }^{1}$, G S Michael ${ }^{1}$, J Kurian ${ }^{2}$, K K Varma ${ }^{3}$, M R Ramesh Kumar ${ }^{1}$, \\ A M Almeida ${ }^{1}$, A S Unnikrishnan ${ }^{1}, \mathrm{~W}$ Fernandes $^{1}, \mathrm{~N}$ Barreto $^{1}$, C Gnanaseelan ${ }^{4}$, \\ R Mathew ${ }^{1}, \mathrm{~K}$ V Praju ${ }^{5}, \mathrm{~V}_{\text {Mahale }}{ }^{1}$ \\ ${ }^{1}$ National Institute of Oceanography, Dona Paula, Goa 403 004, India. \\ ${ }^{2}$ Indian Institute of Science, Bangalore 560 012, India. \\ ${ }^{3}$ College of Fisheries, Kerala Agricultural University, Kochi 682 506, India. \\ ${ }^{4}$ Indian Institute of Tropical Meteorology, Pune 411 008, India. \\ ${ }^{5}$ Cochin University of Science and Technology, Kochi 682 016, India. \\ *e-mail: shenoi@darya.nio.org
}

This paper describes the hydrographic observations in the southeastern Arabian Sea (SEAS) during two cruises carried out in March-June 2003 as part of the Arabian Sea Monsoon Experiment. The surface hydrography during March-April was dominated by the intrusion of low-salinity waters from the south; during May-June, the low-salinity waters were beginning to be replaced by the highsalinity waters from the north. There was considerable mixing at the bottom of the surface mixed layer, leading to interleaving of low-salinity and high-salinity layers. The flow paths constructed following the spatial patterns of salinity along the sections mimic those inferred from numerical models. Time-series measurements showed the presence of Persian Gulf and Red Sea Waters in the SEAS to be intermittent during both cruises: they appeared and disappeared during both the fortnight-long time series.

\section{Introduction}

The southeastern Arabian Sea (SEAS) became the focus of the second phase of the Arabian Sea Monsoon Experiment (ARMEX) (Anonymous 2001) because it hosts the core of the warm pool that engulfs the north Indian Ocean prior to the onset of the summer monsoon (Joseph 1990; Vinayachandran and Shetye 1991; Anonymous 2001). It had been hypothesised that the warm pool plays an important role in the process of monsoon onset over the Indian sub-continent (Joseph 1990; Shenoi et al 1999; Rao and Sivakumar 1999). To study the processes that lead to the formation of the core of the warm pool, two month-long cruises were carried out on board ORV Sagar Kanya during March-April and May-June 2003. The first cruise, SK-190, was conducted during 14th March to 10th April (28 days) and the second cruise, SK193, during 15th May to 19th June (36 days).

A total of 547 profiles of temperature and salinity were collected using a CTD (SeaBird SBE 9/11 Plus) during the two cruises; see figure 1 for the cruise tracks and table 1 for a summary of the observations. Five sections - two cross-shore sections ( $\mathrm{A}$ and $\mathrm{C}$ ), one alongshore section on the continental slope (D), one meridional section along $71^{\circ} 45^{\prime} \mathrm{E}(\mathrm{B})$, and one zonal section along $7^{\circ} 54^{\prime} \mathrm{N}$ (E) - were covered during SK-190; sections A-D were covered at the beginning of the cruise, and section $\mathrm{E}$ at the end. Two cross-shore sections (C, a repeat of the SK-190 section C, and G, a repeat of the section made off Goa during the summer monsoon of 2002 (Shankar et al 2005)) and one long alongshore section (F) were covered during SK-193; section $\mathrm{C}$ (sections $\mathrm{F}$ and $\mathrm{G}$ ) was (were) covered

Keywords. Warm pool; monsoon; circulation; upwelling. 


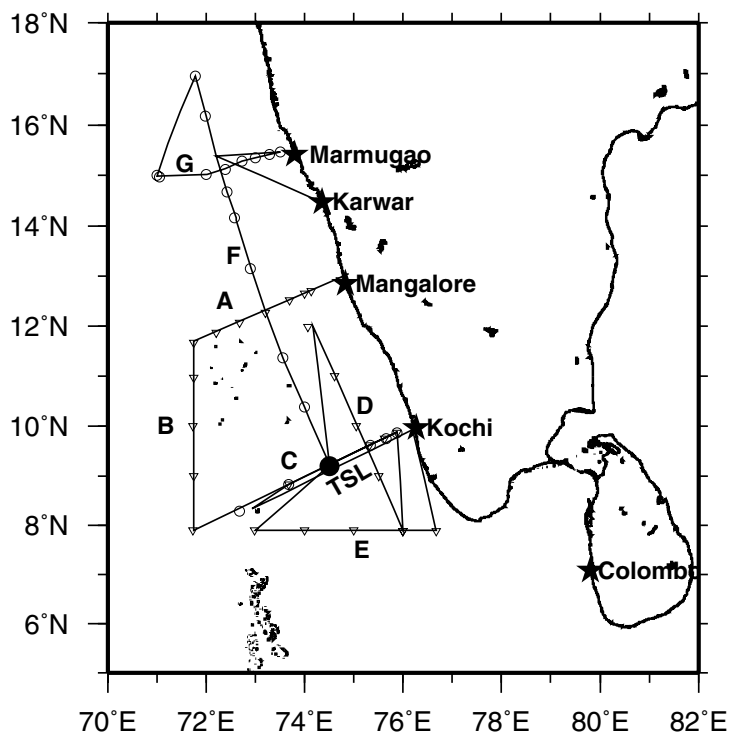

Figure 1. Map showing the hydrographic stations occupied during 14th March to 10th April 2003 (sections A to E; open triangles), and during 15th May to 19th June 2003 (sections $\mathrm{C}$ and $\mathrm{F}$; open circles). Section $\mathrm{C}$ was repeated during both cruises (triangles overlap the circles). The time series location occupied for about 15 days during both cruises is marked as TSL.

Table 1. Days on which the sections and time series were covered. Some stations on the sections are common to two sections; hence, the number of profiles shown in figures 2 and 3 may differ from the number of stations listed below. The time-series location (TSL) lies on section C.

\begin{tabular}{|c|c|c|c|c|}
\hline Cruise & $\begin{array}{l}\text { Section/ } \\
\text { time series } \\
\text { location }\end{array}$ & $\begin{array}{c}\text { Number } \\
\text { of } \\
\text { profiles }\end{array}$ & Start date & End date \\
\hline \multirow{6}{*}{$\begin{array}{l}\text { SK-190 } \\
\text { (14th March- } \\
\text { 10th April } \\
\text { 2003) }\end{array}$} & $\mathrm{A}$ & 8 & $14 / 03 / 03$ & $15 / 03 / 03$ \\
\hline & B & 5 & $16 / 03 / 03$ & $17 / 03 / 03$ \\
\hline & $\mathrm{C}$ & 5 & $18 / 03 / 03$ & $19 / 03 / 03$ \\
\hline & $\mathrm{D}$ & 5 & $20 / 03 / 03$ & $22 / 03 / 03$ \\
\hline & $\mathrm{E}$ & 5 & 08/04/03 & $09 / 04 / 03$ \\
\hline & TSL & 179 & $23 / 03 / 03$ & $07 / 04 / 03$ \\
\hline \multirow{4}{*}{$\begin{array}{l}\text { SK-193 } \\
\text { (15th May- } \\
\text { 19th June } \\
\text { 2003) }\end{array}$} & $\mathrm{C}$ & 6 & $21 / 05 / 03$ & $22 / 05 / 03$ \\
\hline & $\mathrm{F}$ & 10 & $07 / 06 / 03$ & $14 / 06 / 03$ \\
\hline & G & 7 & $15 / 06 / 03$ & $16 / 06 / 03$ \\
\hline & TSL & 173 & $22 / 05 / 03$ & $07 / 06 / 03$ \\
\hline
\end{tabular}

near the beginning (end) of the cruise. About half the time during each cruise, however, was devoted to a fortnight-long, two-hour-interval time series at $74^{\circ} 30^{\prime} \mathrm{E}, 9^{\circ} 13^{\prime} \mathrm{N}$. The time-series location (TSL) was selected after examining a climatology of sea surface temperature (SST) constructed from the weekly data set of Reynolds and Smith (1994) to ensure that the time series would sample the core of the warm pool (Shenoi et al 1999; Rao and Sivakumar 1999; Anonymous 2001) while staying clear of the regime of coastal dynamics: the TSL is about $220 \mathrm{~km}$ offshore; this is more than the local Rossby radius of deformation.

Part of the time-series data have already been analysed to delineate the processes leading to the formation and collapse of the warm pool (Shenoi et al 2004, 2005). We first describe the hydrography and circulation in the upper ocean (section 2) and then the deeper water masses (section 3). Section 4 concludes the paper.

\section{Hydrography and circulation in the upper ocean}

In this paper, we define the upper ocean to be limited to the regime of influence of the high-salinity Arabian Sea High Salinity Water (ASHSW) and the low-salinity Bay of Bengal Water (BBW). We first describe the hydrography and circulation as seen in the sections; then we describe the timeseries observations.

\subsection{Sections}

Vertical sections of temperature and salinity for SK-190 are shown in figure 2. There was no sign of coastal upwelling in sections A and C in midMarch; weak upwelling in the top $100 \mathrm{~m}$ was evident in section E in early April. The low-salinity surface layer was thicker $(\sim 40 \mathrm{~m})$ in the south (sections $\mathrm{C}$ and $\mathrm{E})$ than in the north $(\sim 15 \mathrm{~m}$ in section A). The surface salinity increased poleward (compare sections $\mathrm{C}$ and $\mathrm{E}$ with section $\mathrm{A}$ ). This was also evident in sections $\mathrm{B}$ and $\mathrm{D}$, there being an abrupt change in salinity at $10^{\circ} \mathrm{N}$ in the former. The increase in salinity is particularly rapid near the northern limit of section B; a similar transition around $13^{\circ} \mathrm{N}$ is seen in an analogous section during March 1977 (Babu et al 1980). The highsalinity layer below the surface low-salinity layer was thicker and saltier in the north. These patterns are consistent with the idea of low-salinity BBW intruding into the SEAS during winter (see, for example, Wyrtki 1971; Shenoi et al 2004; Shankar et al 2004).

There was also strong cross-shore variation in salinity on these sections. The surface salinity was lowest at the eastern and western ends of sections $\mathrm{A}$ and $\mathrm{C}$, appearing as two low salinity blobs (figure 2). Two blobs of low salinity were seen in section $\mathrm{E}$ also, one in the middle of the section and the other at the offshore end. However, except in section A, where it is spread across the section, the high-salinity water below the low-salinity surface layer hugs the coast.

Vertical sections of temperature and salinity for SK-193 are shown in figure 3. By mid-May, upwelling had strengthened along section $\mathrm{C}$; the 


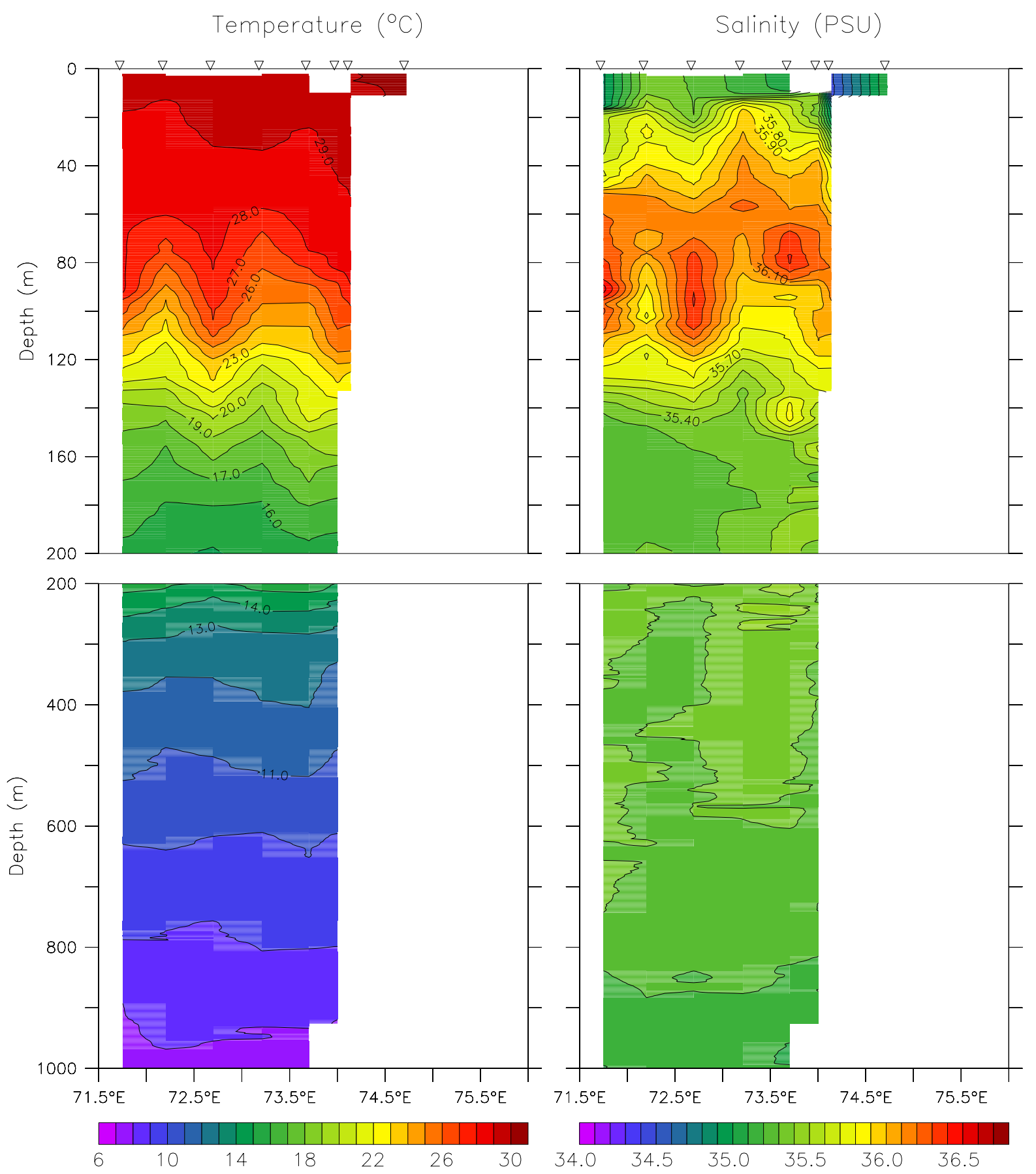

Figure 2(a). Vertical sections of temperature $\left({ }^{\circ} \mathrm{C}\right.$ ) and salinity (PSU) during March-April 2003. (a) Section A, (b) section $\mathrm{B}$, (c) section $\mathrm{C}$, (d) section $\mathrm{D}$, and (e) section E. The inverted triangles mark the station locations. Note the change in vertical scales.

isotherms bent up from $120 \mathrm{~m}$ and the $30^{\circ} \mathrm{C}$ isotherm surfaced near the coast from $50 \mathrm{~m}$. In general, water warmer and saltier compared to March, occupied the top $200 \mathrm{~m}$ along section C. The surface isothermal (isohaline) layer was also warmer (saltier) than in March by one unit. The intense upwelling brought up the high-salinity core, which was at $85 \mathrm{~m}$ in March (figure 2), to $40 \mathrm{~m}$ (figure 3). Contrary to the observation of lowest surface salinities on either ends of section $\mathrm{C}$ in
March, the highest surface salinities were observed on the ends, with waters of lower salinity in the middle.

The alongshore section (section $\mathrm{F}$ ) showed very little variation in temperature in the isothermal layer (figure 3). As expected, the salinity increased from south to north. The increase was prominent above $\sim 60 \mathrm{~m}$. The lowest salinity $(<35.8 \mathrm{PSU})$ occurred in pockets in the south, one near $11^{\circ} \mathrm{N}$ and the other near $9^{\circ} \mathrm{N}$. As in the alongshore section 


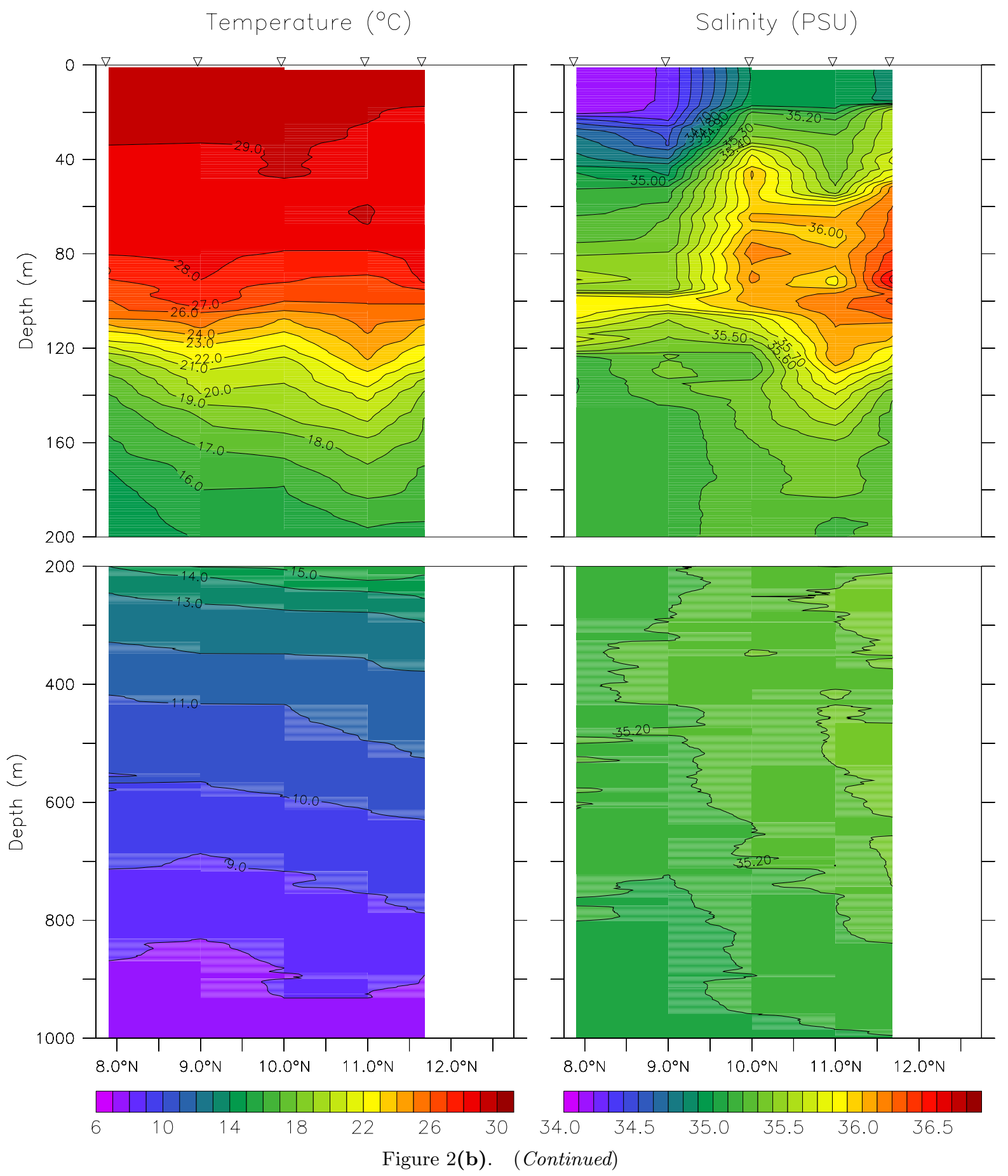

during August 2002 (Shankar et al 2005) and in the section during March 1977 (Babu et al 1980), the strongest salinity gradient was around $13^{\circ} \mathrm{N}$.

The spatial distribution of salinity, with a tendency for low (high) salinity waters to hug the extremes of the sections during March (May-June), with high (low) salinity in the middle, is connected to the flow field that results from the annual cycle of sea level in the SEAS (figure 4). In early December, an equatorward East India Coastal Current (EICC) sets along the east coasts of India and Sri Lanka. The EICC feeds the westward
Winter Monsoon Current (WMC) south of Sri Lanka which ultimately feeds into the poleward WICC along the west coast of India (Shankar et al 2002), bringing low-salinity water from the northern Bay of Bengal into the SEAS (Shetye et al 1991; Han and McCreary 2001). Model studies show that these currents are associated with a downwelling Kelvin wave triggered along the Indian east coast with the collapse of the summer monsoon (McCreary et al 1993, 1996; Shankar et al 2002). The Kelvin wave turns around Sri Lanka to propagate poleward along the Indian west coast, 


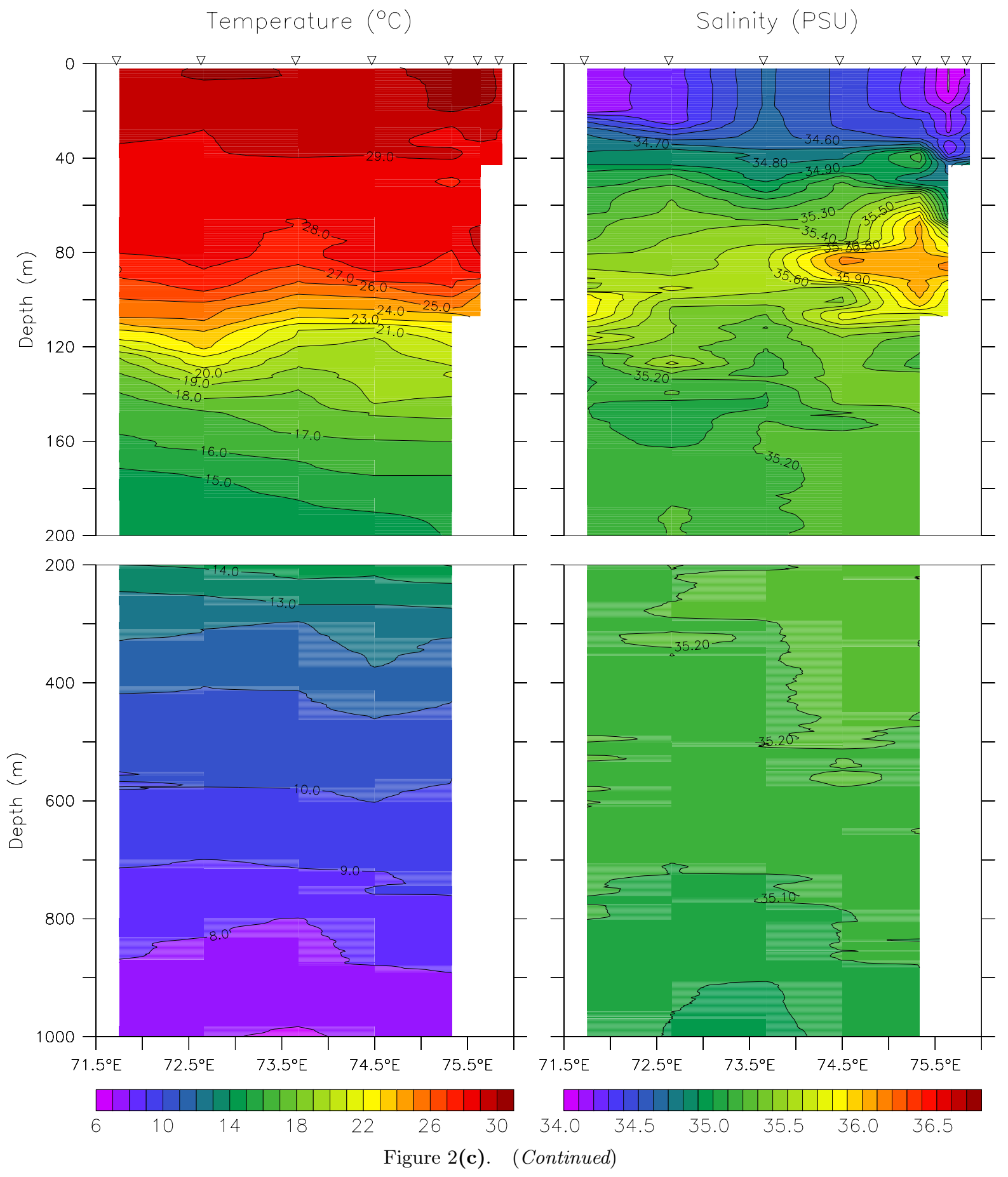

radiating westward propagating Rossby waves and leading to the formation of the Lakshadweep High (LH) in the SEAS (Bruce et al 1994, 1998; Shankar and Shetye 1997). As the LH extends and propagates westward, sometime during February, the high sea level pinches off the coast and a clockwise circulation develops around it with a poleward flow on the western side and an equatorward flow on the eastern side. Later, in June, the LH is replaced by the Lakshadweep Low (LL). Embedded in the LH and LL are smaller eddies (figure 4). The schematic in figure 5 depicts the evolution of circulation in

the SEAS. The WMC, the WICC, and the LH and LL contribute to and alter the flows in the SEAS, and, as a consequence, the spatial distribution of salinity. The salinities along section $\mathrm{C}$ were lower than those along section A because of the advection from the south. Noteworthy however, is that the lowest salinity along these sections occurred at the eastern and western ends (figure 2). Along section B, salinity was low in the south, but increased abruptly north of $10^{\circ} \mathrm{N}$. Along section D, the lowest salinity was seen at $10^{\circ} \mathrm{N}$. This observation can be explained qualitatively by linking it with 


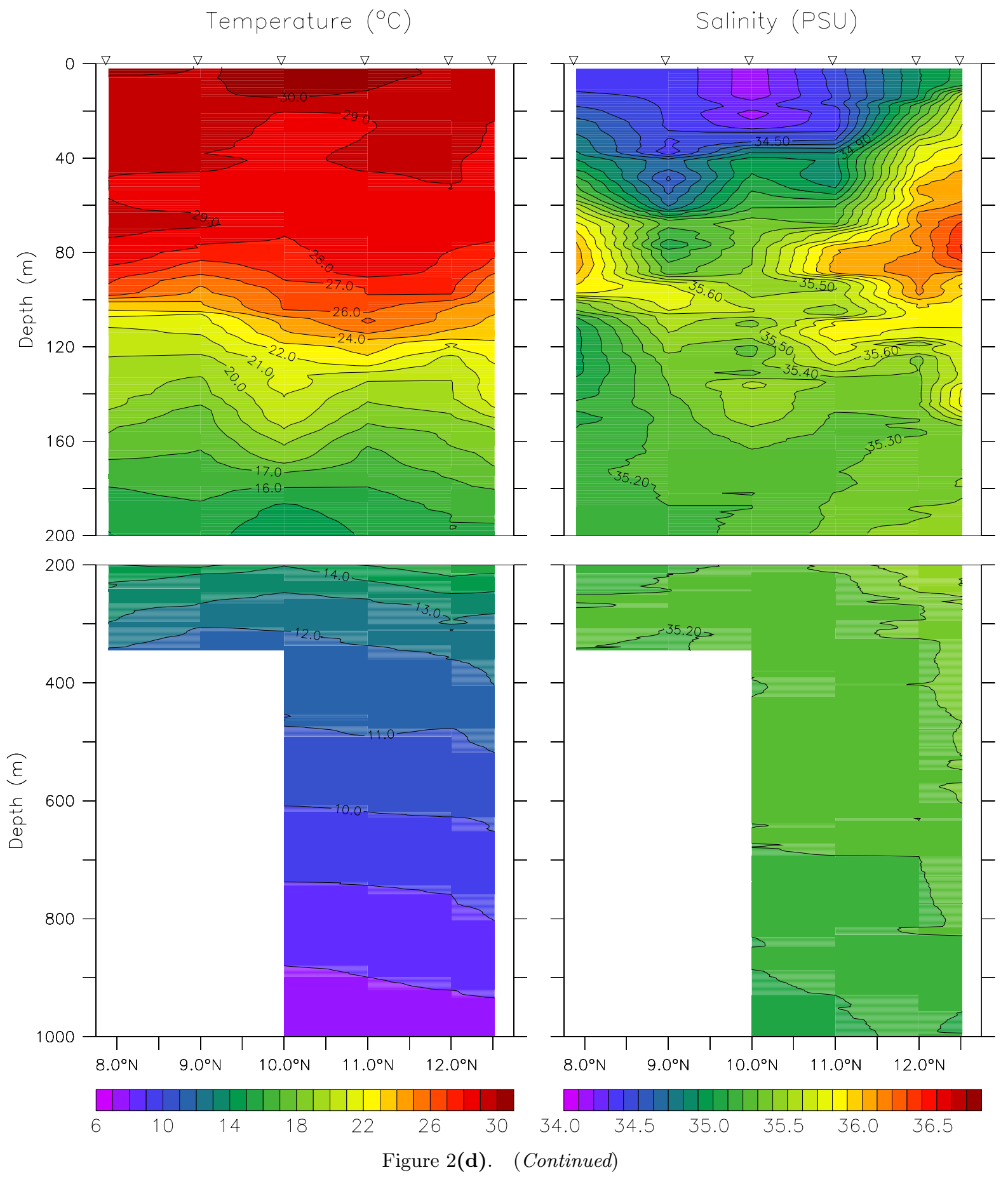

the schematic for March (figure 5). A schematic of flow paths constructed based on the spatial pattern of salinity is shown in figure 6. The WICC that carried the low-salinity waters poleward along the coast initially in November, along with the part of the flow that winds around the LH to flow equatorward on its eastern flank, lowers the salinity at the eastern end of section A. This equatorward flow at the coast, which develops once the high sea level pinches off the coast, also lowers the salinity at stations on section D and at stations on the eastern

end of section C. The WMC that branched off on the west of the LH lowers salinities at stations on the southern end of section B and at the westernmost stations on section $\mathrm{C}$ (see the tracer snapshots in the numerical simulations of Bruce et al 1994 and Plate 3a in Han and McCreary 2001). The converse holds during the summer monsoon, with high-salinity blobs replacing the low-salinity blobs observed during the winter monsoon because the circulation around the LL is opposite to that around the LH (Shankar and Shetye 1997). 


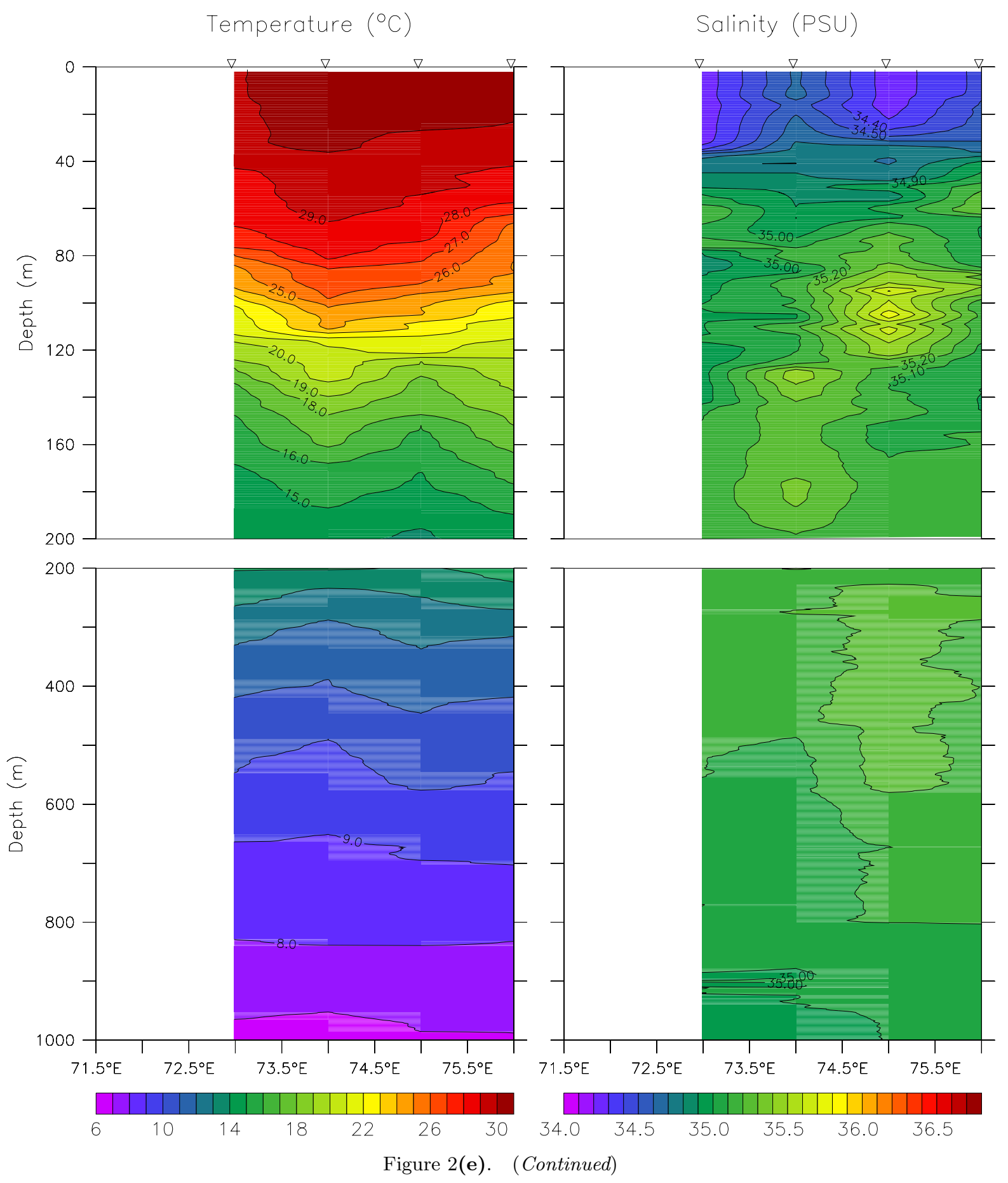

\subsection{Time series}

Time-series measurements of temperature and salinity at the TSL are shown in figure 7 . Since the measurements were made at 2-hour intervals, the effects of internal waves at diurnal and semi-diurnal tidal frequencies are prominent. The harmonic analysis (Anonymous 1996) for the temperature field (figure 8) shows that for SK-190 (SK-193) the amplitudes of the semi-diurnal components $\mathrm{M}_{2}$ and $\mathrm{S}_{2}$ were about $0.4^{\circ} \mathrm{C}$ and $0.3^{\circ} \mathrm{C}\left(0.2^{\circ} \mathrm{C}\right.$ and $0.3^{\circ} \mathrm{C}$ ) at $100 \mathrm{~m}$ for SK-190 (SK-193); the corresponding amplitudes of the diurnal components $\mathrm{O}_{1}$ and $\mathrm{K}_{1}$ were $0.2^{\circ} \mathrm{C}$ and $0.38^{\circ} \mathrm{C}\left(0.45^{\circ} \mathrm{C}\right.$ and $\left.0.5^{\circ} \mathrm{C}\right)$. The most striking change from MarchApril to May-June is in the decrease in the depth range over which the components are significant and the increase in the amplitude of the diurnal components. The former change is due to the decrease in the depth of the surface mixed layer and isothermal layer from March-April to May-June; the amplitudes obtained for the tidal components 


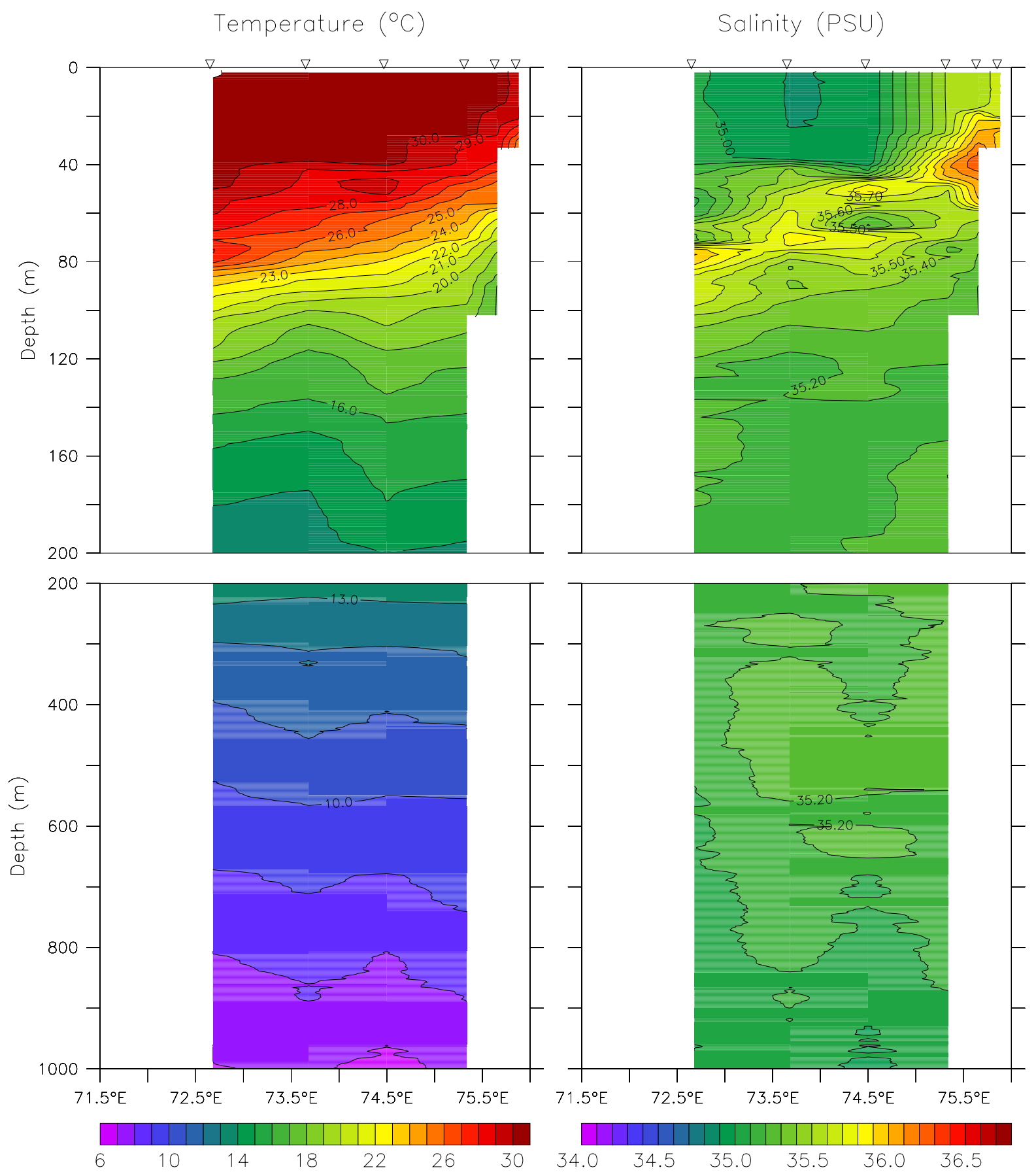

Figure 3(a). Vertical sections of temperature $\left({ }^{\circ} \mathrm{C}\right)$ and salinity (PSU) during May-June 2003. (a) Section C and (b) section F. The inverted triangles mark the station locations. Note the change in vertical scales.

depend on the stratification. The latter change is more complicated because the analysis is incapable of separating the diurnal variability due to the tides from that due to the winds. A Fast Fourier Transform (FFT) of the winds measured on board shows that amplitude at the diurnal (semi-diurnal) period increased by a factor of 2.4 (1.4) from the first time-series to the second. That the winds also exhibit a diurnal variation aliases the tidal signal in the harmonic analysis. Though a more rigorous analysis of the internal tides is beyond the scope of this paper, it is worth noting that they contribute to an error of 4-6 dyn-cm in the $0 / 1000$ dynamic height, comparable to that observed farther north during the summer monsoon of 2002 (Shankar et al 2005). This dynamic-height oscillation due to internal tides is also comparable to the dynamic height difference across the sections described above (considering only stations deeper than $1000 \mathrm{~m}$ ), implying a signal-to-noise 


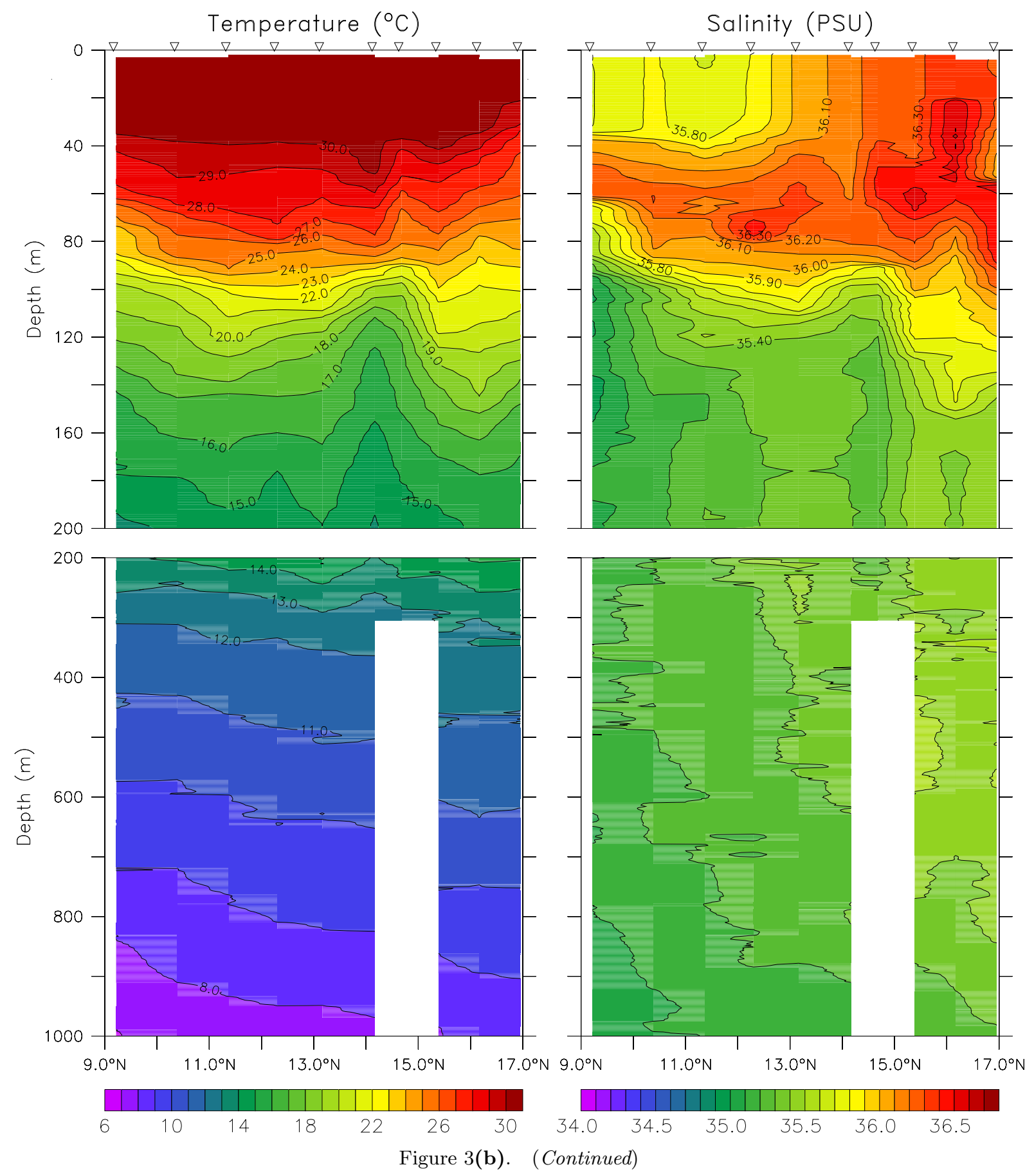

ratio of $\sim 1$; hence, geostrophic computations have not been shown for the sections.

The mean depth of the thermocline, identified with the $25^{\circ} \mathrm{C}$ contour, decreased from $105 \mathrm{~m}$ on 22nd March to $70 \mathrm{~m}$ on 7th April, and then to $60 \mathrm{~m}$ on 7 th June. The rate of upwelling accelerated on a few occasions. One among them was during 3rd7th April; this upwelling burst was forced remotely rather than by the local winds (Shenoi et al 2004). The effects of this upwelling were, however, not felt at the surface because of the high temperature of the mixed layer $\left(>30^{\circ} \mathrm{C}\right)$.

The temperature and salinity in the upper layer $(40 \mathrm{~m})$ were much lower during March-April than during May-June (figure 7). Salinities as low as 34.0 PSU were found near the surface in March-April. The intrusion of low-salinity water in the surface layer displaced the native water, the ASHSW (salinity > 36.0 PSU). The low-salinity BBW glided over the ASHSW and mixed with it rapidly, leaving no discontinuity in salinity at the bottom boundary of the upper layer; patches of ASHSW, however, remained unmixed on 28th29th March and 2nd-3rd April (at $\sim 80 \mathrm{~m}$ ), when 

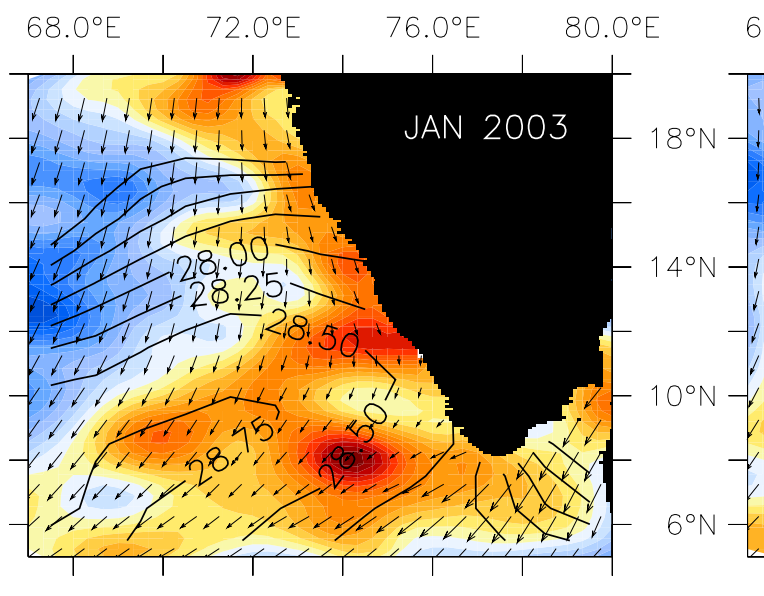

$68.0^{\circ} \mathrm{E}$

$72.0^{\circ} \mathrm{E}$

$76.0^{\circ} \mathrm{E}$

$80.0^{\circ} \mathrm{E}$
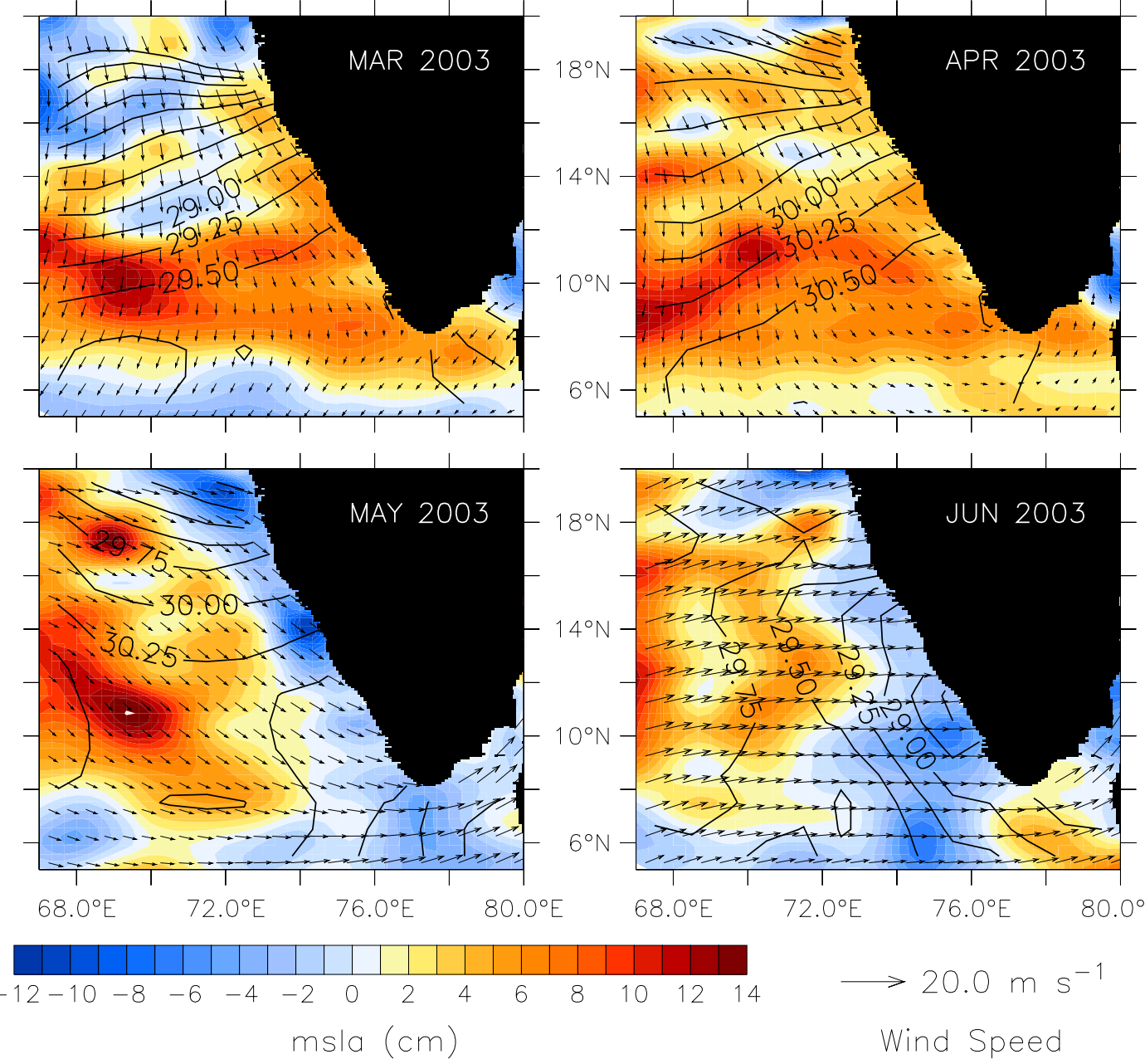

Figure 4. Maps of monthly mean winds, SST, and sea level anomaly in the SEAS during January to June 2003. satellite derived winds, Quikscat (ftp://ftp.ssmi.com), gridded at quarter-degree interval, were used to construct the monthly mean winds (vectors, $\mathrm{m} \mathrm{s}^{-1}$ ). Gridded (one-third degree interval) mean sea-level anomalies available from a LAS server (http://las.aviso.oceanobs.com) were used to construct the monthly mean anomalies of sea level (colour fill, cm). Optimally interpolated weekly SST (Reynolds and Smith 1994) available from ftp://podac.jpl.nasa.gov/pub/sea-surface-temperature/ reynolds/oisst/data was used to construct the monthly mean SST (contours, ${ }^{\circ} \mathrm{C}$ ).

blobs of low-salinity water $(\sim 34 \mathrm{PSU})$ appeared at the surface. In the absence of local rains (no rain was recorded on board the ship or at nearby coastal stations during the time series or immediately before it), the possible causes are advection or redistribution within the SEAS by the smaller eddies that constitute the LH (see figure 4); it is unlikely that low-salinity BBW are still brought into the SEAS during March-April because the WMC weakens considerably by then 

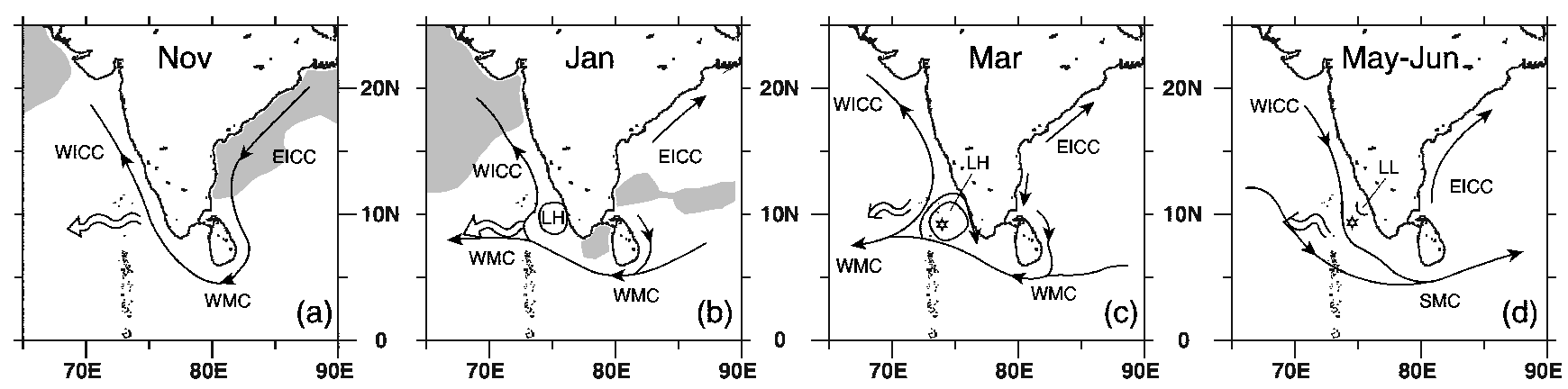

Figure 5. Schematic showing the evolution of circulation in the SEAS during November-June. The acronyms are as follows: EICC, East India Coastal Current; WMC, Winter Monsoon Current; WICC, West India Coastal Current; LH, Lakshadweep (sea level) high and LL, Lakshadweep (sea level) low. In November, the EICC feeds into the WICC through the westward WMC south of India. The shaded regions are where the ocean loses heat to the atmosphere owing to air-sea fluxes. The westward radiation of Rossby waves, depicted by the wiggly arrow, leads to the formation of the LH by January. The LH pinches off the coast by February; the WICC then flows equatorward off the southwest coast of India, forcing upwelling in a narrow band hugging the coast, but it flows poleward along the rest of the west coast. By March, the LH spreads farther west and a high in SST forms over the LH. In May, the WICC reverses its direction all along the west coast of India and flows equatorward, bringing high-salinity water from the northern Arabian Sea. The upwelling that appeared near the coast in February spreads farther west and results in the formation of the LL. The LL and the influx of high-salinity water from the north hasten the annihilation of the barrier layer, leading to the collapse of the high in SST and the warm pool early in June.

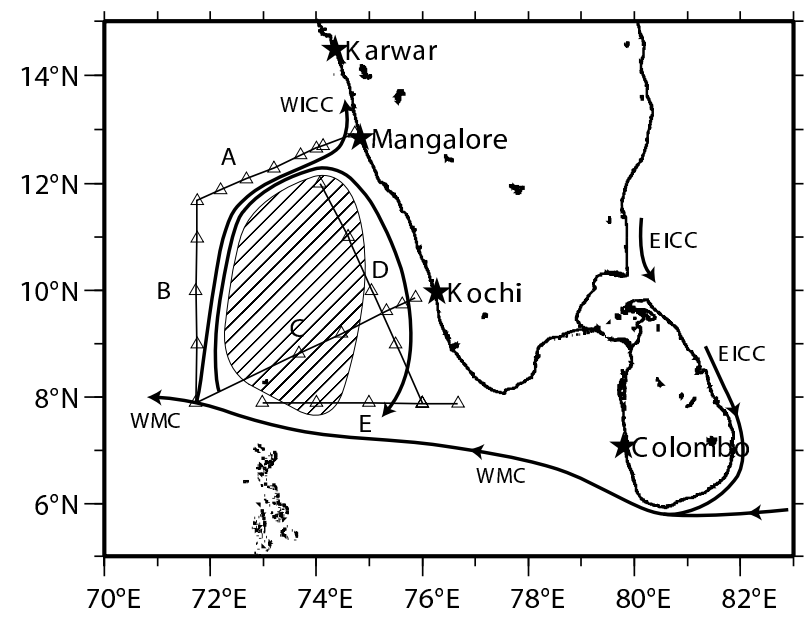

Figure 6. Schematic of flow paths constructed based on the spatial distribution of salinity along the sections during March-April 2003. Note the similarity in the flow paths with the schematic for March in figure 5.

(Shankar et al 2002). The presence of the lowsalinity blobs increases stratification and inhibits mixing. The mixing of these two water masses of widely varying salinities left behind layers of saltier water interlaced with fresher water at the boundaries of mixing. This is more evident in the TS diagram, in which two maxima (at $\sigma_{t}=23$ and $\left.24.4 \mathrm{~kg} \mathrm{~m}^{-3}\right)$, separated by a minimum, are seen (figure 9a). Similar interleaving of water masses was observed in a CTD time series in $100 \mathrm{~m}$ water depth off Kochi during April 1991 and May-June 1992 (Hareeshkumar et al 1995; Hareeshkumar and Mohankumar 1996); the appearance of pockets of low-salinity water coincided in these time series with reversals in the currents.

The May-June time series also showed lower salinity in the upper layer ( $\sim 40 \mathrm{~m}$ deep), but the salinity was higher than during March-April. The salinity increased abruptly on 26th May, and remained more or less the same till 4th June, when another abrupt increase in salinity occurred. The second increase lasted only for two days. Similar changes occurred in the ASHSW layer that existed below the low-salinity layer. The ASHSW was present at shallower depths $(\sim 50-60 \mathrm{~m})$ than in March-April. Also seen again were the double maxima (figure 9b; see also Kumar and Prasad 1999) and the streaks of low-salinity water interlaced with layers of high-salinity water. The upper maximum, which coincides with the core of ASHSW, is the more prominent of the two (figure 9b).

\section{Deep water masses}

In this paper, we identify 'deep water masses' to be those below the regime of the near-surface high-salinity ASHSW and low-salinity BBW. The water masses known to occur between these surface water masses and $1000 \mathrm{~m}$ are the Persian Gulf Water (PGW) and Red Sea Water (RSW), which are embedded in the Indian Central Water.

The temperature structure below $200 \mathrm{~m}$ was similar for all sections during March-April (figure 2). The salinity structure, however, showed patches of higher salinity (35.4-35.6 PSU) hugging the shelfbreak and slope in the depth range 180-600 m. The 


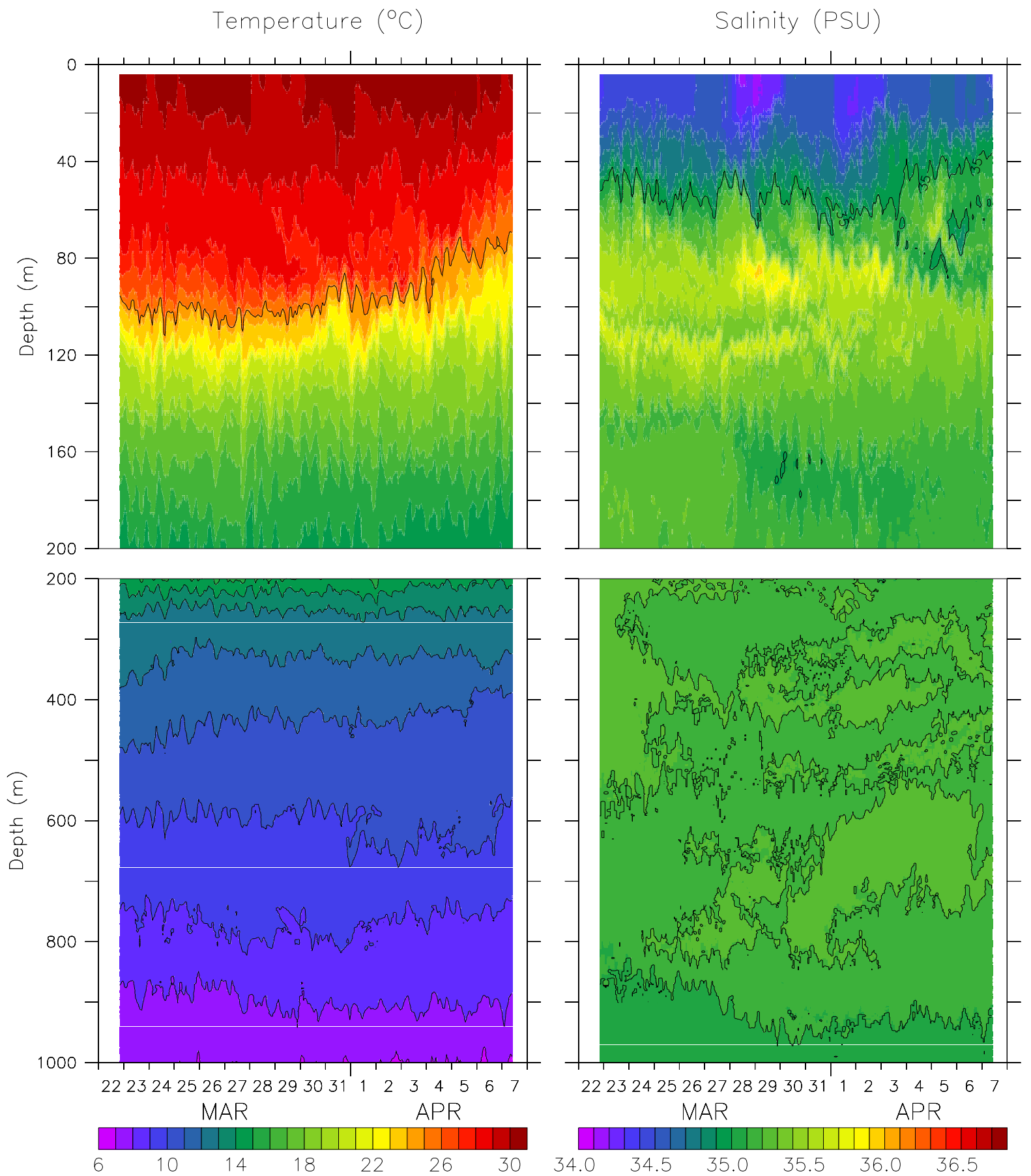

Figure 7(a). Time series of vertical profiles of temperature $\left({ }^{\circ} \mathrm{C}\right)$ and salinity (PSU) during 22nd March-7th April (a) and 23rd May-7th June 2003 (b) at TSL $\left(74^{\circ} 30^{\prime} \mathrm{E}, 9^{\circ} 13^{\prime} \mathrm{N}\right.$ in the SEAS). The measurements were made every two hours. The $25^{\circ} \mathrm{C}$ and 35.0 PSU contours are marked in the top panels. The contours in the bottom panels are marked every $1^{\circ} \mathrm{C}$ and 0.1 PSU.

alongshore sections (sections B and D) also showed such patches, but with a poleward increase in salinity. The $\sigma_{t}$ levels of these patches correspond to $26.0-27.4 \mathrm{~kg} \mathrm{~m}^{-3}$, the range of the PGW and RSW: the PGW (RSW) spreads between the $\sigma_{t}$ levels $26.3-26.5 \mathrm{~kg} \mathrm{~m}^{-3}\left(27.0-27.3 \mathrm{~kg} \mathrm{~m}^{-3}\right)$ (Rochford 1964; Shenoi et al 1993). During MarchApril, the core of the RSW was at $27.15 \mathrm{~kg} \mathrm{~m}^{-3}$ (figures 2, 9, and 10). The PGW signal is more prominent than the RSW. This was also true during May-June on section C (figure 3).

PGW and RSW were also conspicuous at the TSL during both cruises (figure 9). The PGW, having temperature and salinity in the ranges $13-14^{\circ} \mathrm{C}$ and $35.2-35.25 \mathrm{PSU}$, was present between 200 and $300 \mathrm{~m}$ and was centred at the $\sigma_{t}$ surface 


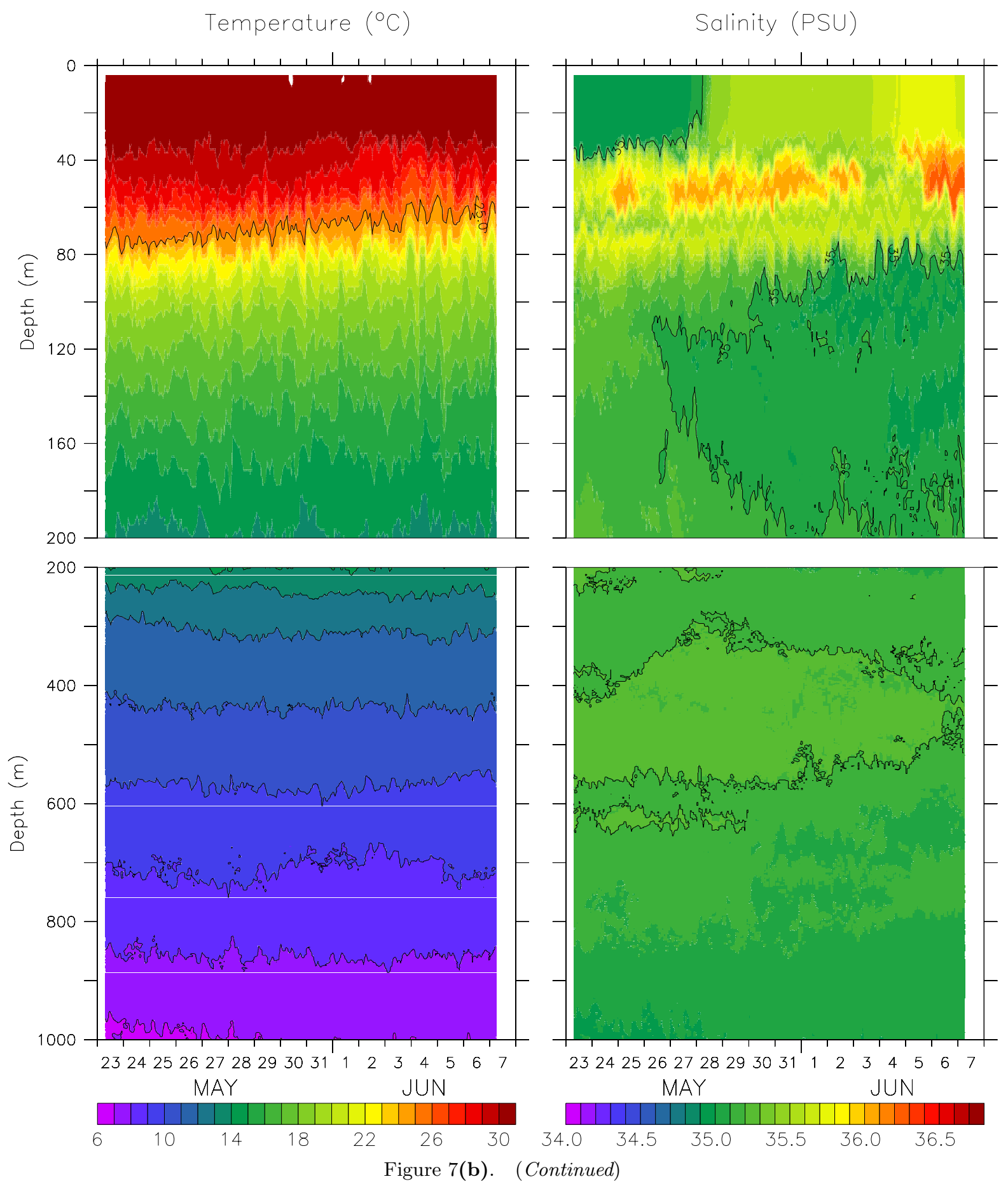

$26.4 \mathrm{~kg} \mathrm{~m}^{-3}$. Its temperature varied between 13 and $14^{\circ} \mathrm{C}$ and salinity from $35.2-35.25$ PSU. The RSW, having temperature and salinity in the ranges $10-12^{\circ} \mathrm{C}$ and $35.2-35.3 \mathrm{PSU}$, was present between 600 and $700 \mathrm{~m}$ and was centred at $\sigma_{t}=27.15 \mathrm{~kg} \mathrm{~m}^{-3}$ during March-April. During May-June, the core of the RSW was at $\sigma_{t}=27.05 \mathrm{~kg} \mathrm{~m}^{-3}$, but RSW was also present at its more normal level of $\sigma_{t}=27.20 \mathrm{~kg} \mathrm{~m}^{-3}$. Signals of the Arabian Sea Salinity Minimum (ASSM; Shenoi et al 1993) and PGW were stronger during
May-June, when it was spread over a larger $\sigma_{t}$ range $\left(24.50-25.75 \mathrm{~kg} \mathrm{~m}^{-3}\right)$ between the depths 100 and $200 \mathrm{~m}$ (figure 7 ).

Like the ASHSW and BBW, the deep water masses also exhibited considerable intermittency (figure 9). Not all profiles at the TSL showed the salinity maxima associated with PWG and RSW; often, they showed even salinity minima at those density levels. For example, the salinity maximum associated with RSW concentrated between the $\sigma_{t}$ levels 27.05 and 27.25 was evident during 4th April 


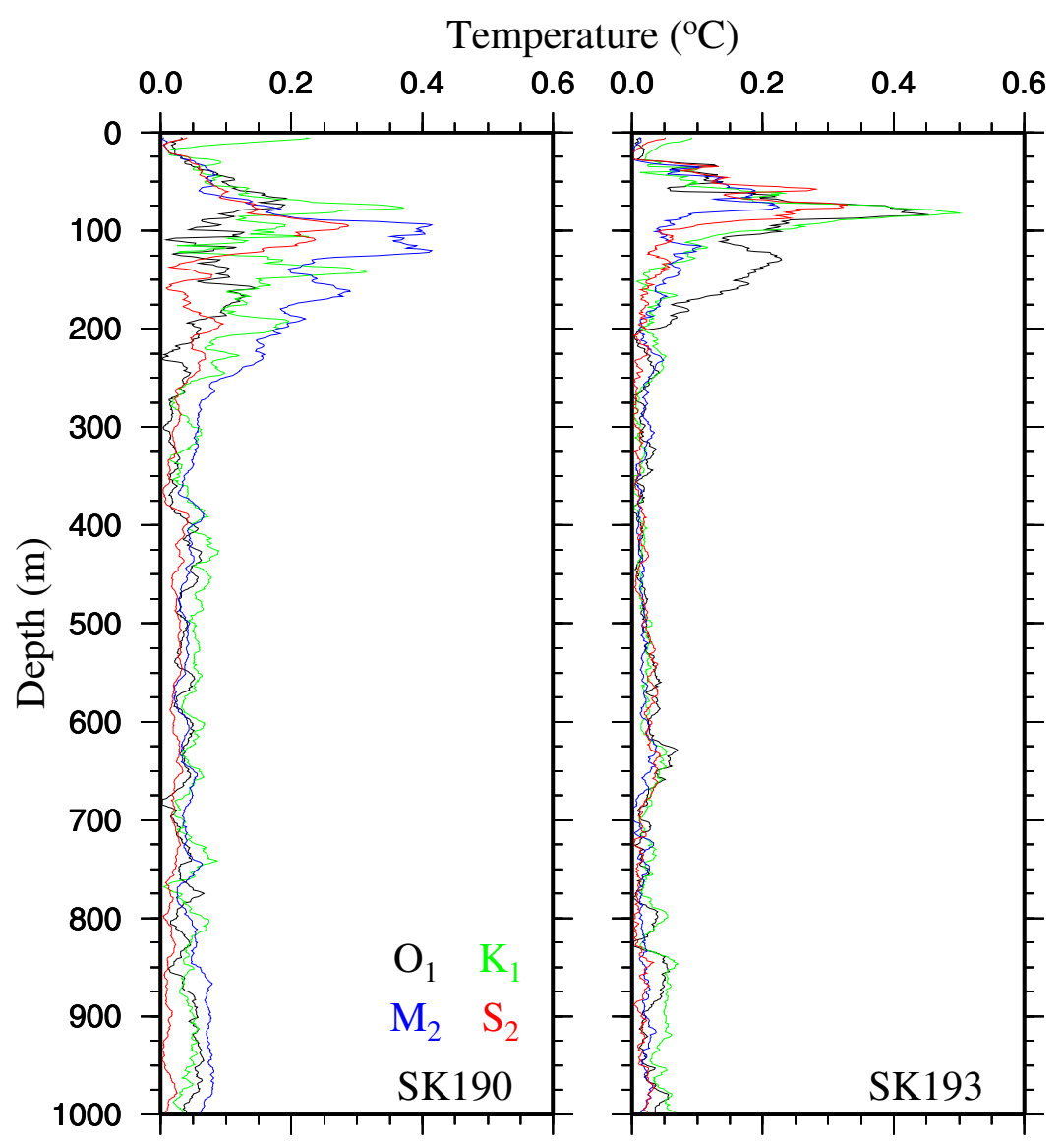

Figure 8. Semi-diurnal $\left(\mathrm{M}_{2}\right.$ and $\left.\mathrm{S}_{2}\right)$ and diurnal $\left(\mathrm{O}_{1}\right.$ and $\left.\mathrm{K}_{1}\right)$ components of the temperature $\left({ }^{\circ} \mathrm{C}\right)$ field for the SK-190 (left) and SK-193 (right) time series.

2003 in the profiles made at 14:00, 16:00, and 18:00 hours (figure 10, the red curves), and it continued to be seen till 6th April 22:00 hours (the green curves for 6th April 18:00, 20:00, and 22:00 hours). Subsequent profiles, starting from 00:00 hours on 7th April (figure 10, black curves), however, started showing the disintegration of the maximum, leading to a minimum within a few hours (blue curves at 07:00, 09:45, and 13:00 hours on 7th April). This implies that the flow of RSW to the TSL occurred intermittently rather than continuously; also, there was considerable temporal variability in the volume of RSW seen here. Similar intermittency was seen in the PGW and ASSM (see figure 9).

\section{Discussion}

Most of the features and the overall structure of temperature and salinity across the sections were similar to climatology (Levitus and Boyer 1994; Levitus et al 1994; Rao and Sivakumar 2003), except for the warmer (by $\sim 0.5^{\circ} \mathrm{C}$ ) and saltier (by $\sim 0.5 \mathrm{PSU}$ ) waters in the upper ocean observed in the two cruises. The higher temperature and salinity are not surprising because the summer monsoon of 2002 saw one of the worst droughts recorded in India (Gadgil et al 2002); a weak monsoon is known to leave the ocean warmer and saltier, but also contributing was the delayed onset of the summer monsoon in 2003 (Vinayachandran 2004). That the hydrography is in accordance with climatology is also not surprising because the seasonal cycle is known to be very strong and repetitive in this region (Banse 1968; Sharma 1968; Johannessen et al 1981; Schott and McCreary 2001).

The CTD time-series measurements brought out the considerable intermittency that is present in the water-mass signals. The major water masses of the Arabian Sea, ASHSW, PGW, and RSW, were all observed at the TSL. On several occasions (within a span of a few hours), however, the salinity maximum associated with them was replaced by a minimum and vice versa (figures 9 and 10). Such appearances and disappearances cannot be associated with the variability due to internal waves because the changes are neither gradual nor periodic. These changes, which occur in a short span of time, are due to the intermittency in the appearance of water masses at 
23 Mar to 7 Apr 2003

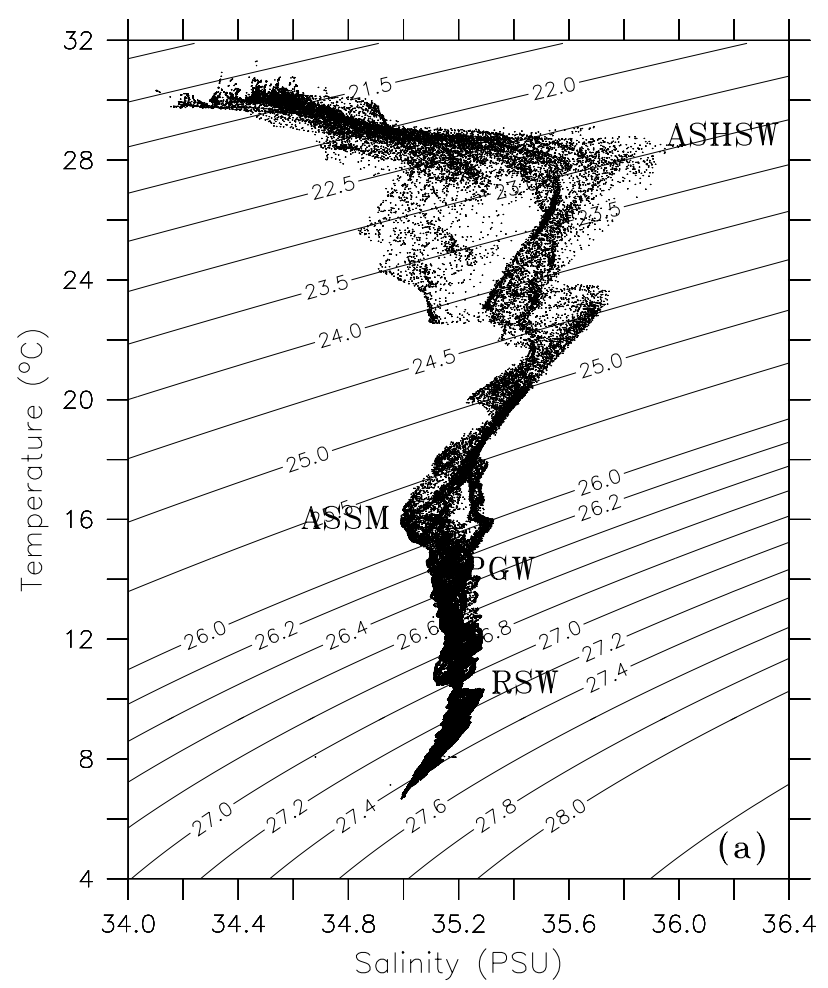

22 May to 7 Jul 2003

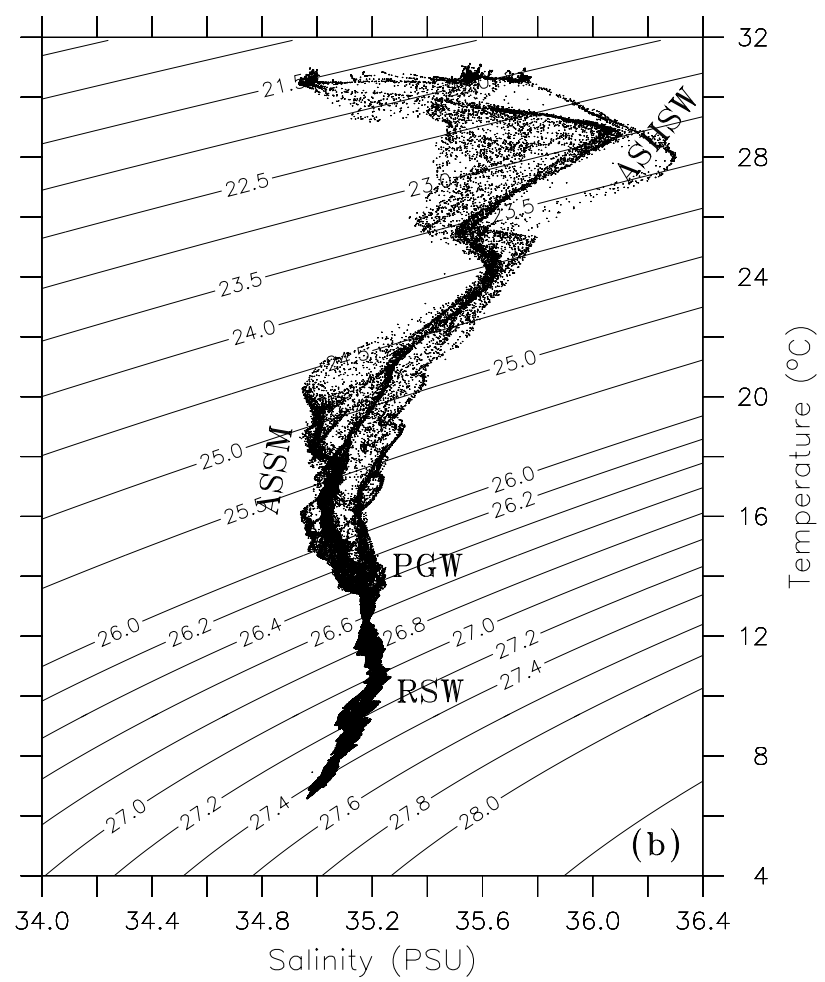

Figure 9. Temperature-salinity (TS) diagram for all profiles collected at TSL during (a) 22nd March-7th April and (b) 23rd May-7th June 2003.

the TSL. Similar intermittency can therefore be expected in the rest of the SEAS and has also been observed earlier on the continental shelf in the SEAS (Hareeshkumar et al 1995) and in the rest of the eastern Arabian Sea (Shankar et al 2005). Hareeshkumar et al (1995) and Hareeshkumar and Mohankumar (1996) noted that such pockets of waters of different salinity coincided with reversals in currents. Shankar et al (2005) argued that the intermittency of the RSW in the eastern Arabian Sea may be due to the occurrence of the RSW even in the northwestern Arabian Sea in the form of patches or lenses (Shapiro et al 1994; Beal et al 2000), which are advected to the northern end of the Indian west coast; since the RSW moves southward along the Indian west coast (Babu et al 1980; Shankar et al 2005), an intermittent RSW signal is not surprising in the SEAS. Since the PGW signal is much stronger farther north along the Indian west coast because of the increasing proximity to the source, this signal did not exhibit as much intermittency as the RSW in the time-series observations of Shankar et al (2005); in the SEAS, however, the PGW signal is weaker, and shows much more intermittency.

This intermittency, and that these water mass layers are often thin, has implications. The earlier technology of sampling with bottles was very likely to miss the signal because the water samples were collected only at certain depths. Hence, the often 20-40 m thick cores of the PGW or RSW between 200 and $700 \mathrm{~m}$, where water samples were collected usually at intervals of over $100 \mathrm{~m}$, would have missed the signal, and this is the likely reason for the noted 'absence' of the PGW, and often of the RSW, in the SEAS (Babu et al 1980; Shetye et al 1990; Shenoi et al 1993; Prasad et al 2001); some bottle casts, however, did show the presence of RSW (Varkey et al 1979). Another salinity signal that needed CTD measurements for its elucidation is the interleaving of high and low-salinity layers where the high-salinity ASHSW and low-salinity BBW mix; these interleaved layers are also as thin as $20 \mathrm{~m}$ (figure 7) and are subject to considerable vertical movement owing to internal tides.

Does this mean that these signals will be captured only if the timing of sampling is right? A larger data set will be required to answer such questions, and to analyse this intermittent signal for hidden periodicities. In conclusion, however, we note that even though the ARMEX cruises described here were designed to study the warm pool and its possible role in monsoon onset, implying a focus on observations relevant to air-sea interaction, the CTD time-series measurements, the first such measurements in this region, will help 


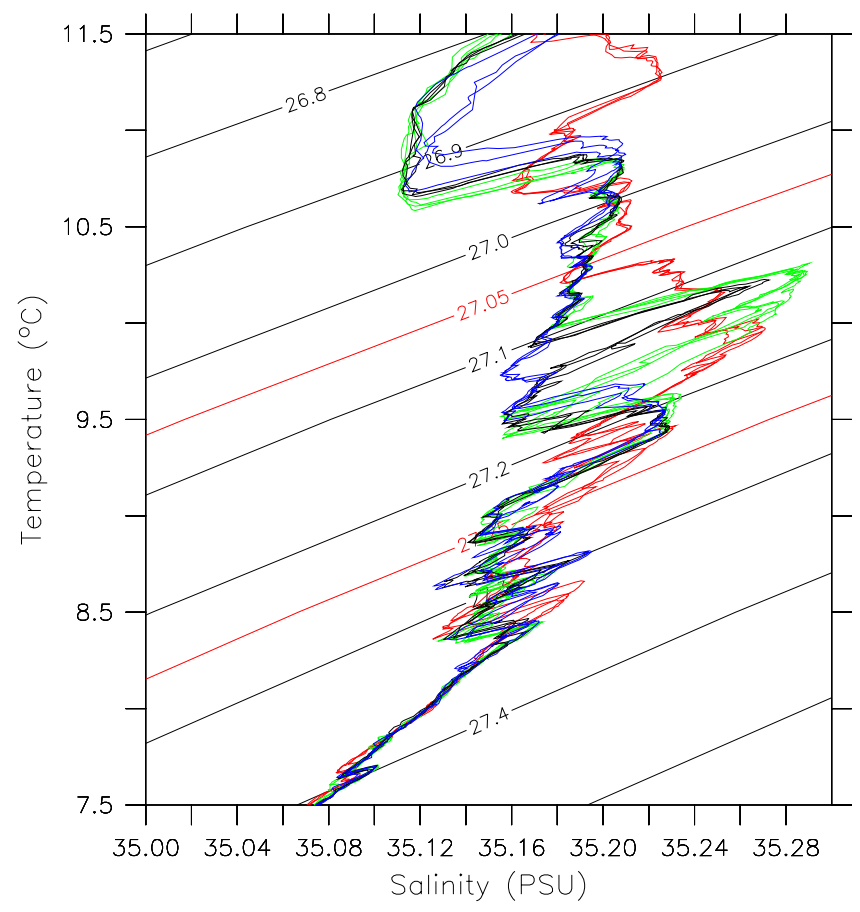

Figure 10. TS diagram for some of the profiles collected at TSL during March-April 2003. To highlight the variability of RSW, only a part of the TS diagram is shown. The three red curves represent the profiles at 14:00, 16:00 and 18:00 hours on 4th April, green curves profiles at 18:00, 20:00 and 22:00 hours on 6th April, black curves profiles at 20:00 and 22:00 hours on 6th April and at 00:00 hrs on 7th April, and blue curves profiles at 07:00, 09:45, 13:00 hours on 7th April.

to reinterpret some of the earlier observations on deeper water masses.

\section{Acknowledgements}

A national programme like ARMEX would not have been possible without the support and cooperation of several groups. We thank them all. We thank the Department of Science and Technology (DST) and the Department of Ocean Development for financial support, DST's 'Working Group on Ocean-Atmosphere Field Experiments under ICRP' and Satish Shetye for guidance during the field programme, the masters, crew, and supporting engineers on board ORV Sagar Kanya for rendering considerable assistance during the cruises, and the other cruise participants, especially G S Bhat, for their support. The altimeter sea level, QuikScat wind, and SST data were downloaded from the AVISO (http://las.aviso.oceanobs.com), SSMI (ftp://ftp.ssmi.com), and PODAAC (ftp:// podac.jpl.nasa.gov/pub/sea-surface-temperature/ reynolds/oisst/data) web sites, respectively. G S Bhat made available the wind data from $O R V$ Sagar Kanya. We thank F Durand for useful discussions and $\mathrm{K}$ Banse and an anonymous reviewer for their comments, which helped us to focus the manuscript and improve it. Pramila Gawas, $\mathrm{R}$ Uchil, and A Mahale helped with some of the figures; the software packages Ferret and GMT were used extensively. The harmonic analysis for tides was done using the package TASK. This is NIO contribution 3977.

\section{References}

Anonymous 1996 TASK: Tidal Analysis Software Kit, Proudman Oceanographic Laboratory, Bidston, UK.

Anonymous 2001 Arabian Sea Monsoon Experiment (ARMEX): Science plan, Department of Science and Technology, New Delhi.

Babu R V, Varkey M J, Kesava Das V and Gouveia A D 1980 Water masses and general hydrography along the west coast of India during early March; Indian J. Mar. Sci. 9 82-89.

Banse K 1968 Hydrography of the Arabian Sea shelf of India and Pakistan and effects on demersal fishes; Deep-Sea Res. 15 45-79.

Beal L, Ffield A and Gordon A L 2000 Spreading of Red Sea overflow waters in the Indian Ocean; J. Geophys. Res. 105 8549-8564.

Bruce J G, Johnson D R and Kindle J C 1994 Evidence for eddy formation in the eastern Arabian Sea during the northeast monsoon; J. Geophys. Res. 99 7651-7664.

Bruce J G, Kindle J C, Kantha L H, Kerling J L and Bailey J F 1998 Recent observations and modeling in the Arabian Sea Laccadive High region; J. Geophys. Res. 103 7593-7600.

Gadgil S, Srinivasan J, Nanjundiah R S, Krishnakumar K, Munot A A and Rupakumar K 2002 On forecasting the Indian summer monsoon: The intriguing summer of 2002; Curr. Sci. 83 394-403.

Han W and McCreary J P 2001 Modeling salinity distributions in the Indian Ocean; J. Geophys. Res. 106 859-877.

Hareeshkumar P V, Mohankumar N and Radhakrishnan K G 1995 Multiple sub-surface maxima in vertical salinity structure: A case study; Indian J. Mar. Sci. 24 $77-81$.

Hareeshkumar P V and Mohankumar N 1996 On the flow and thermohaline structure off Cochin during premonsoon season; Cont. Shelf Res. 16 457-468.

Johannessen O M, Subharaju G and Blindheim J 1981 Seasonal variation of the oceanographic conditions off the southwest coast of India during 1971-75. Fiskdir. Skr. Ser. HavUnders. 18 247-261.

Joseph P V 1990 Warm pool over the Indian Ocean and monsoon onset; Tropical Ocean-Atmosphere Newsletter $531-5$.

Kumar S P and Prasad T G 1999 Formation and spreading of Arabian Sea High-Salinity water mass J. Geophys. Res. 104 1455-1464.

Levitus S and Boyer T P 1994 World Ocean Atlas 1994: Volume 4: Temperature, NOAA Atlas NESDIS 4.

Levitus S, Burgett R, Boyer T P 1994 World Ocean Atlas 1994: Vol. 3: Salinity, NOAA Atlas NESDIS 3.

McCreary J P, Kundu P K and Molinari R L 1993 A numerical investigation of the dynamics, thermodynamics and mixed-layer processes in the Indian Ocean; Progr. Oceanogr. 31 181-244.

McCreary J P, Han W, Shankar D and Shetye S R 1996, Dynamics of the East India Coastal Current, 2. Numerical solutions; J. Geophys. Res. 101 13,993-14,010. 
Prasad T G, Ikeda M and Kumar S P 2001 Seasonal spreading of Persian Gulf water mass in the Arabian Sea; J. Geophys. Res. 106 17,059-17,071.

Rao R R and Sivakumar R 1999 On the possible mechanisms of the evolution of a mini-warm pool during the pre-summer monsoon season and the onset vortex in the southeastern Arabian Sea; Q. J. R. Meteorol. Soc. 125 787-809.

Rao R R and Sivakumar R 2003 Seasonal variability of sea surface salinity and salt budget of the mixed layer of the north Indian Ocean; J. Geophys. Res. 1083009 doi:10.1029/2001JC000907.

Reynolds R and Smith T 1994 Improved global sea surface temperature analyses using optimum interpolation; J. Clim. 7 929-948.

Rochford D J 1964 Salinity maxima in the upper $1000 \mathrm{~m}$ of the north Indian Ocean; Aust. J. Mar. Freshw. Res. 15 $1-24$.

Schott F and McCreary J P 2001 The monsoon circulation in the Indian Ocean; Progr. Oceanogr. 51 1-123.

Shankar D, Gopalakrishna V V, Shenoi S S C, Durand F, Shetye S R, Rajan C K, Zacharias J, Araligidad N and Michael G S 2004 Observational evidence for westward propagation of temperature inversions in the southeastern Arabian Sea; Geophys. Res. Lett. 31 doi:10.1029/2004GL19652.

Shankar D and Shetye S R 1997 On the dynamics of the Lakshadweep high and low in the southeastern Arabian Sea; J. Geophys. Res. 102 12,551-12,562.

Shankar D, Vinayachandran P N and Unnikrishnan A S 2002 The monsoon currents in the north Indian Ocean; Progr. Oceanogr. 52 63-120.

Shankar D, Shenoi S S C, Nayak R K, Vinayachandran P N, Nampoothiri G S, Almeida A M, Michael G S, Ramesh Kumar M R, Sundar D and Sreejith O P 2005 Hydrography of the eastern Arabian Sea during summer monsoon 2002; J. Earth Syst. Sci., this issue.

Shapiro G L, Meschanov S L and Polonsky A B 1994 Red Sea water lens formation in Arabian Sea; Oceanology 36 $24-31$.
Sharma G S 1968 Seasonal variation of some hydrographic properties of the shelf waters off the west coast of India; Bull. Nat. Inst. Sci. India 38 263-275.

Shenoi S S C, Shetye S R, Gouveia A D and Michael G S 1993 Salinity extrema in the Arabian Sea; In: Monsoon Bio-geochemistry (eds) V Ittekkot and R R Nair, Mitt. Geol.-Paläont. Inst. Univ. Hamburg 76 37-49.

Shenoi S S C, Shankar D and Shetye S R 1999 On the sea surface temperature high in the Lakshadweep Sea before the onset of the southwest monsoon; J. Geophys. Res. 104 15,703-15,712.

Shenoi S S C, Shankar D and Shetye S R 2004 Remote forcing annihilates barrier layer in southeastern Arabian Sea; Geophys. Res. Lett. 31 L05307, doi:10.1029/2003GL019270.

Shenoi S S C, Shankar D, Gopalkrishna V V and Durand F 2005 Role of ocean in the genesis and annihilation of the core of the warm pool in the southeastern Arabian Sea; Mausam 56 147-168.

Shetye S R, Gouveia A D, Shenoi S S C, Sundar D, Michael G S, Almeida A M and Santanam K 1990 Hydrography and circulation off the west coast of India during southwest monsoon; J. Mar. Res. 48 359-378.

Shetye S R, Gouveia A D, Shenoi S S C, Michael G S, Sundar D, Almeida A M and Santanam K 1991 The coastal current off western India during the northeast monsoon; Deep-Sea Res. 38 1517-1529.

Varkey M J, Das V K and Ramaraju D V 1979 Physical characteristics of the Laccadive Sea (Lakshadweep); Indian J. Mar. Sci. 8 203-210.

Vinayachandran P N and Shetye S R 1991 The warm pool in the Indian Ocean; Proc. Indian Acad. Sci. (Earth Planet. Sci.) $100165-175$.

Vinayachandran P N 2004 Summer cooling of the Arabian Sea during contrasting monsoons; Geophys. Res. Lett. 31 L13306, doi:10.1029/2004GL019961.

Wyrtki K 1971 Oceanographic atlas of the International Indian Ocean Expedition, National Science Foundation, Washington, D.C., U.S.A. 